2006

\title{
21st Century Darling
}

Mark Swan

Cedarville University

Follow this and additional works at: https://digitalcommons.cedarville.edu/cedarvillereview

Part of the Poetry Commons

DigitalCommons@Cedarville provides a publication platform for fully open access journals, which means that all articles are available on the Internet to all users immediately upon publication. However, the opinions and sentiments expressed by the authors of articles published in our journals do not necessarily indicate the endorsement or reflect the views of DigitalCommons@Cedarville, the Centennial Library, or Cedarville University and its employees. The authors are solely responsible for the content of their work. Please address questions to dc@cedarville.edu.

\section{Recommended Citation}

Swan, Mark (2006) "21st Century Darling," Cedarville Review. Vol. 9, Article 2.

Available at: https://digitalcommons.cedarville.edu/cedarvillereview/vol9/iss1/2 


\section{1st Century Darling \\ Creative Commons License \\ (C) $(\mathbb{\theta} \Theta \Theta$}

This work is licensed under a Creative Commons Attribution-Noncommercial-No Derivative Works 4.0 License. 


\section{5t CENTURY DARLING}

\section{Mark Swan}

If

We got in the way

Of

Your Hobbies

It's only

Because

We

Are

We are

Too. We are

And disillusionment patterns are suicidal patterns

There is a break, there is a break in episodes that matter

And if Life is good with cigarettes

Then Life is good with cigarettes

And heartbreaking patterns are trivial inane patterns

Without a break, without a break in heartbreaks that matter

And if Life is good with paper planes

Then Life is good with paper planes

We

Are only poison oak

Or

Gold Mari-Golds?

That counts

For

Something

Or

Is it

Too. Is it

And the words are spiritual and the words are mist

There was a tangible animal that was always missed

The shock is only your heart aflutter

Your shock is when your heart's aflutter

Logically, wonderfully, a hero dies logically

In white, a bite, let's make moves theologically

And if Life is good with no regret

Then Life is good with no regret

Th-e

Reis noreas

$\mathrm{O}$

nto wo rr

Anymore. 